\title{
Environmental Impact Assessments in Investment Process - Legal and Methodological Aspects
}

\author{
Jolanta Harasymiuk ${ }^{1 *}$ \\ ${ }^{1}$ University of Warmia and Mazury in Olsztyn, Faculty of Geodesy, Geospatial and Civil Engineering, \\ ul. Heweliusza 4, 10-724 Olsztyn, Poland \\ * Corresponding author's e-mail: jolanta.harasymiuk@uwm.edu.pl
}

\begin{abstract}
For a decade or so, environmental impact assessments have been a tool used in investment process in order to evaluate the impact of a planning document or a given construction project on the environment. The legal regulation in force approaches determining the elements making up each assessment selectively. There is also a lack of methodological guidelines pertaining to the rules of assessment making (such guidelines were prepared in reference of e.g. motorways and dual carriage ways or wind power plants). It hinders understanding the aims and the range of environmental impact assessments by society and investors as well as obtaining acceptance for making them by the latter. The article presents the issue of the principal environmental assessments (strategic environmental impact assessment, environmental impact assessment and impact assessment on Natura 2000 sites) in the legal and methodological context. The conducted studies showed that unstable legal system in the field of environmental assessments endangers correctness and punctuality of preparation of an building investment.
\end{abstract}

Keywords: environmental impact assessment, legal regulations, investment process, construction projects.

\section{INTRODUCTION}

Building investments are attributed with the role of one of the most important factors in the socio-economic development locally, regionally and nation-wide. The investment dynamics and the increase of the Gross Domestic Product place Poland among the leaders of the Central Europe. The literature on the subject emphasizes the close relation of a life cycle of a building structure (being a final product of investment process) with its environment [Kasprowicz 2016, Szafranko 2017]. At the stage of a construction, buildings take up a given area changing the natural terrain relief, destroying flora and introducing barriers for animals. An increase of air pollutant emission and noise resulting from the operation of building equipment and an increased traffic of lorries on the site. At the stage of exploitation, there is a constant impact of the investment on the atmospheric environment, the acoustic climate and the health condition of the people. At the stage of liquidation, we face the problem of, among others, air pollution, noise, vibrations, waste and other nuisance connected with the machine operation used in demolition work. A tool, which enables the identification of possible dangers from the part of planned investment activities, protect the natural resources and human health as well as to counteract the environment degradation is an environmental impact assessment. In the light of legal regulations, such an assessment is an important element of an investment process, no matter of the subject (municipal planning documents, individual undertakings). A strategic environmental assessment (SEA) is initiated during the preparation of a local spatial development plan, whereas an environmental impact assessment (IEA) is issued in the process of giving decision of environmental conditions. An environmental impact assessment of a building investment of a Natura 2000 site (HA) should be understood as an assessment of the impact of this investment limited to the examination of its impact on a Natura 2000 
site. In face of instability of legal regulations concerning the principles of conducting environmental assessments [Tkaczyński 2009, Brodawka 2014] there is a need to check and up date these regulations at the trade, domestic, European and international levels. Because of the lack of complex guidelines on the manner of conducting environmental assessments in the investment process both in the literature and the practice, it is justifiable to present their methodological aspectsunderstood as a set of the activities and measures used to ensure their effectiveness. The aim of the article was to show the most important problems of methodological environmental impact assessments (pertaining to the principles of qualification of investments, the principles of impact prognosis and the principles of documentation evaluation). It also offers a detailed analysis of legal bases from the viewpoint of their influence on the preparation of a building investment.

\section{MATERIALS AND METHODS}

The research shown in the article was initiated with an analysis of different rank of legal regulations (international, European, domesticand trade ones)concerning the basic environmental impact assessments in the investment process. In order to present the organisational system of such assessments, the elements of the structural method of designing of socio-technical system were used. Methodical considerations appertaining to the way of conducting environmental assessments were started with an overview of the electronic databases of Scopus and Web of Science in order to find the published articles presenting the methods of assessment of environmental impact. Since a basic element of each assessment is the preparation of a specific environmental documentation, the research was supplemented with an analysis of methodological chapters of the environmental documentation submitted by investors in the years of 2016-2018. The analysed documents pertained to:

- proceedings on strategic environmental impact assessments of the projects of local plans for the municipality of Olsztyn,

- proceedings on issuing a decision of the environmental conditions for wind power plants conducted by the Regional Directorate of Environment Protection in Olsztyn.
- proceedings on justification of conducting a habitat assessment for SFRs done by the Regional Directorate of Environment Protection in Olsztyn (RDEP, in short).

\section{Analysis of legal regulations on environmental impact assessment}

While conducting basic environmental impact assessments, one of the key issues are legal regulations. The most important of which are presented in the division on:

- international regulations:

- the United Nations Convention on Biological Diversity,

- the United Nations Convention on the Law of the Sea (UNCLOS),

- the United Nations Framework Convention on Climate Change (UNFCCC),

- the United Nations Convention to Combat Desertification in Those Countries Experiencing Serious Drought and/or Desertification, Particularly in Africa.

- European regulations:

- Directive of the European Parliament and the Committee of 2014/52/UE changing the Directive of 2011/92/UE on assessment of the impact of some public and private undertakings on the natural environment (the EIA Directive, in short),

- Directive of the European Parliament and the Committee of 2001/42/WE of 27 June 2001 on assessment of the impact of some plans and programs on the natural environment (the SEA Directive, in short),

- Directive of the Committee 92/43/EWG of 21 May 1992 on the protection of natural habitats of wild fauna and flora (the Habitat Directive, in short),

- Directive of the European Parliament and the Committee of 2009/147/WE of 30 November 2009 on the protection of wild birds (the Birds Directive, in short),

- Directive of the European Parliament and the Committee of 2003/4/WE on the public access to the information on natural environment,

- domestic regulations:

- the Parliamentary act of 3 October 2008 on the access to the information of the environment and its protection, participation of society in the environment protection 
and environmental impact assessments (referred later as the 2008 Parliamentary act),

- the Decree of the Minister Councilof 9 November 2010 on undertakings possibly impacting the environment in a significant degree,

- trade regulations:

- the Parliamentary act of 7 July 1994 Building law.

The legal bases of environmental impact assessments and their position in the hierarchy of the legal system are shown in Figure 1.

Because of the limited length of the article, the text refers to the regulations of key importance. At the international level, environmental impact assessments are mainly determined by international environmental conventions and other legal instruments of the "soft law" character. The convention on bio-diversity plays the main role. According to the convention, the parties should introduce the procedures of environmental impact assessment for these building investments which can have a harmful influence on bio-diversity.

In the European scale, the requirements pertaining to the environmental impact assessments originate mainly from the EU law. The basic role is played by: EIA Directive (determines the rules of an environmental impact assessment of building investments), the SEA Directive (pertain to the projects of documents of strategic character) and the habitat directive (concerns individual undertakings and projects of plans and programs) ${ }^{1}$.

At the domestic level, the 2008 Parliamentary act is the principal document regulating the issue of environmental impact assessments in the process of investment. Since the moment of its passing, it has been amended several times and the changes made introduce additional requirements for investors and building investments (the list of the most important changes enclosed in Table 1). In order to limit the risk of non-uniformly enforced law, the Ministry of Regional Development prepared successive versions of (2007,

\footnotetext{
${ }^{1}$ While the EIA Directive pertains to the I and II kinds of undertakings as determined in supplements and the SEA Directive partially to the projects determining frameworks of these undertakings, the habitat directive (and also the SEA Directive in its part by its reference to the habitat directive) does not point to specific types of undertakings, projects of plans or programs taking as a reference point a possible impact Natura 2000 sites.
}

2015, 2017) on handling environmental impact assessment for the undertakings co-financed from domestic and regional Operation Programs. The catalogue of undertakings requiring the necessity of preparing an environmental impact assessment, which in the opinion of investors is still not univocal ${ }^{2}$,was also amended several times (2005, 2007, 2010, 2013, 2015, 2017 and 2019-project). The lack of a univocal interpretation of the changes has had a negative influence on preparation of building investment on time and inexpensively [Tkaczyński 2009, Rakoczy and Pchałek, 2010, Rak 2014]. The newest changes in the Parliamentary act of Environment Protection in the project from June 2019 seem to be advantageous from the viewpoint of investors (shortening the waiting time for issuing the decision on the environmentally-related conditions for construction project) but yet they present threats (limiting the number of procedure parties).

The principal trade regulation pertaining to EIA is the Building code Parliamentary act. According to the act, an imitation of complicated building work can occur only after obtaining a final agreement for the construction activities. The act does not explicitly determine the kinds of construction work which require such a permit, except building work on a monument entered in the list of historic buildings and undertakings requiring EIA as well as those on Natura 2000 sites.

According to the valid legal regulations, each country should prepare its own system of environmental assessment. Designing such a system requires determining its elements and the mechanisms generating information about a condition of these elements.

The functioning of the organizational and information subsystems is especially important from the view point of reliability of conducted environmental assessments. The first of the abovementioned systems is shown in Figure 2. The conducted research proves though, that the second system does not work properly. It manifests itself in the discrepancies between the data stored in the database of SEA (the database is kept by the General Director of Environment Protection) and the data disclosed by chosen cities of the

\footnotetext{
${ }^{2}$ In the case of motorways and dual carriageways, the General Board of Domestic Roads prepared an interpretation of the regulations from the years of 2011-2014 concerning the qualification of these undertakings for an environmental impact assessment.
} 


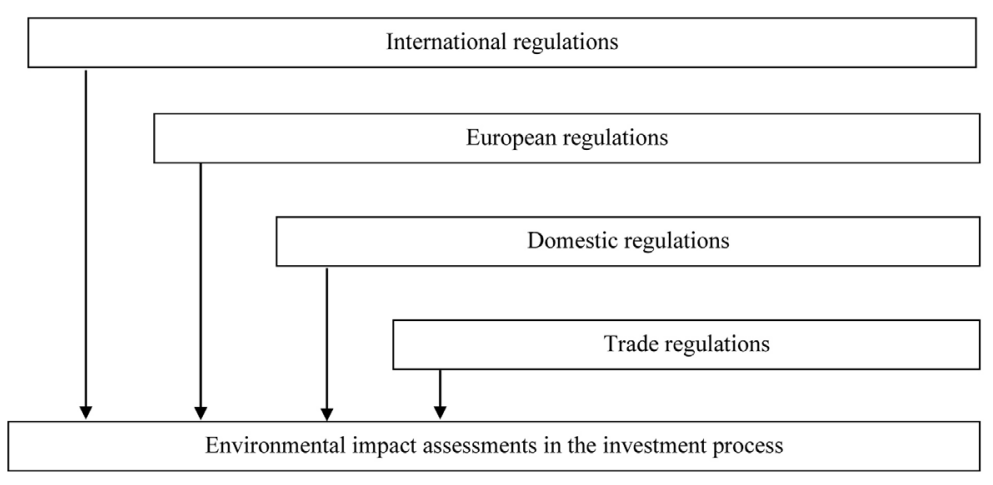

Fig. 1. Legal regulations on environmental impact assessment in the investment process in Poland

administrative rank of districts. This fact prevents achieving the purpose for which the database is kept, i.e. the possibility of monitoring environmental assessments by the society and investors.

\section{Analysis of methodological problems of environmental impact assessments in investment process in Poland}

Considerations on the methods of conducting environmental assessments in investment process should be started with a definition of the notion of assessment. Definitions of such a notion are given in the act (2008). However, they are incomplete because they enumerate their chosen components leaving out the activities initiated by the investors and efforts serving to monitor their effectiveness. The full list of the components of EIA is presented in the article [Harasymiuk 2017], and HA in the reference [Harasymiuk 2016]. The components of SEA were analysed in the article [Harasymiuk and Drozd 2019].

In the qualification procedure of a building investment, a coherent system of substantial criteria is not applied for conducting of EIA and HA. Instead of measureable criteria, in the case of the classic assessment, only the circumstances included in art. 63.1 of the 2008 Parliamentary actare taken into account (kind and characteristics of an undertaking, localisation and the kind and scale of a possible impact), and in HA, additionally the principle of caution (it issues form the collective law) and the constitutional principle of securing the rights of property (issues form the constitution of the republic of Poland). From the analysis of justification for the decisions of the Regional Directoriate of Environment Protection in Olsztyn, both not stating and stating the obligation of conducting a habitat assessment in the years of 2016-2018 issues a lack of substantial references to all the required qualification conditions. It shows the need to prepare a coherent system of the criteria qualifying an undertaking to carry out such an assessment. The possibility of exemption of the project of local plans from SEAs, as stated in the 2008 Parliamentary act calls for greater precision. Such an exemption may pertain to slight modifications of the assignation of earlier accepted plans, with the assumption of a lack of a considerable impact of the document project on the environment. The abovementioned criteria have an indefinite character.

The key element of each of the basic environmental assessments is foreseeing the impact of an undertaking/results of preparing a spatial plan for the definite elements of the environment conditions. The methodological guidelines in the field pertain only to a few kinds of building investments (national roads [Manual of good practices... 2008], wind power plants [Stryjecki and Mielniczuk, 2011], railway investments) and chosen kinds of impacts (for example impacts of wind farms on birds [Chylarecki et al. 2011] or bats [Kepel, Ciechanowski and Jaros 2011]). In the case of the undertakings which may considerably and permanently influence the environment, it is necessary to conduct a detailed quantitativequalitative analysis of an impact in order to determine an acceptance of their realization and to choose an optimal variant of activities which minimize or compensate their effects. From the analysis of the documents submitted by investors in the analysed period of time, the issues that were described the kinds of impact in each environmental assessment in least detail are cumulative impacts. In the literature [Smit and Spaling, 1995, Wärnbäckand and Hilding-Rydevik, 2009, Gerleeand Kaim, 2011], numerous tools to analyse and assess cumulative effects of undertakings have been known for many years. The lack 
Table 1. The most important changes in environmental impact assessments issuing from the 2008 Parliamentary act and its amendments

\begin{tabular}{|c|c|c|}
\hline $\begin{array}{l}\text { Name and } \\
\text { category of } \\
\text { regulation }\end{array}$ & $\begin{array}{c}\text { Most } \\
\text { important } \\
\text { amendments }\end{array}$ & Characteristics of changes \\
\hline \multirow[t]{4}{*}{$\begin{array}{l}\text { The Parliamentary } \\
\text { act of } 3 \text { October } \\
2008 \text { on access to } \\
\text { the information of } \\
\text { the environment } \\
\text { and its protection, } \\
\text { participation of } \\
\text { society in the } \\
\text { environment } \\
\text { protection- } \\
\text { commonly applied } \\
\text { regulation of } \\
\text { domestic scope }\end{array}$} & $\begin{array}{l}\text { Amendment of } \\
21 \text { May } 2010\end{array}$ & $\begin{array}{l}\text { - } \\
\text { - } \\
\text { were extended (a slight modification of the already accepted documents), } \\
\text { for the procedure of working out strategic assessments and undertakings } \\
\text { assessments a new organ was introduced, namely the Director of the } \\
\text { Maritime Office (for the terrain within their field of activity), } \\
\text { - } \quad \begin{array}{l}\text { the possibility of suspension of administrative procedures were made more } \\
\text { precise for the time of submitting a report of environmental impact by the }\end{array} \\
\text { investor, } \\
\text { - } \\
\text { the possibility of placing a decision on environmental conditions to another } \\
\text { subject was introduced and the regulations concerning a final decision were } \\
\text { made more precise, } \\
\text { the regulations concerning the time of using an environmental decision for } \\
\text { completion of an investment undertaking were made more precise, } \\
\text { the necessity of obtaining a decision of environmentally-related conditions for } \\
\text { construction projects realised on the basis of notification of building activities } \\
\text { or notification of a change of a building use was introduced. }\end{array}$ \\
\hline & $\begin{array}{l}\text { Amendment of } \\
9 \text { October } 2015 \\
\text {-changes in force } \\
\text { since December } 2015\end{array}$ & 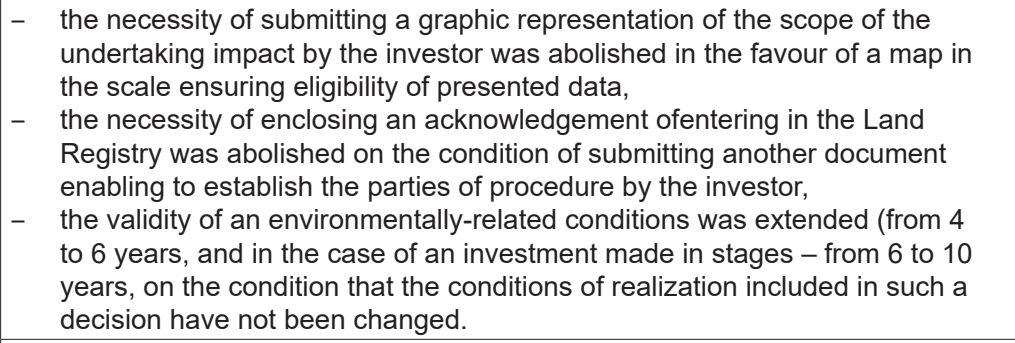 \\
\hline & $\begin{array}{l}\text { Changes in force } \\
\text { since 1. January } \\
2017\end{array}$ & $\begin{array}{l}\text { - } \\
\text { the requirements pertaining to the environmental documentation were made } \\
\text { stricter. The substantial content of reports was extended with: a description } \\
\text { of the results of an inventory of nature, a description hydro-morphological, } \\
\text { physicochemical, biological and chemical properties of waters"included in } \\
\text { the scope of the expected impact of an undertaking (despite the fact the } \\
\text { regulations of the Water Law talk about the "condition" of these elements } \\
\text { and not about the"properties"), a description of the impact of the undertaking } \\
\text { on climate, a description of the assessment of cumulative impact of the } \\
\text { undertakings under construction, in existence or planned ones). The } \\
\text { requirements pertaining to the authors were also made stricter (an author } \\
\text { of a prognosis of an environmental impact, of a report on the impact of a } \\
\text { construction projecton the environment and of a report of the impact of } \\
\text { a construction project on Natura } 2000 \text { site, and in the case of a team of } \\
\text { authors, a person who graduated from determined studies or having a 5-year } \\
\text { experience in preparing such documents may be in charge), } \\
\text { the possibility of issuing an environmental decision in their own interest for } \\
\text { the construction projects for which investor is a unit of self-government was } \\
\text { abolished, } \\
\text { the time of submitting remarks and notions to the environmental } \\
\text { documentation of an investment by representatives of society was extended } \\
\text { to } 30 \text { days, } \\
\text { financial penalties for not observing the conditions established in an } \\
\text { environmental impact assessment were introduced. }\end{array}$ \\
\hline & $\begin{array}{l}\text { Changes in force } \\
\text { since 1. January } \\
2018 \text { (related to the } \\
\text { changes introduced } \\
\text { in the Water Law) }\end{array}$ & 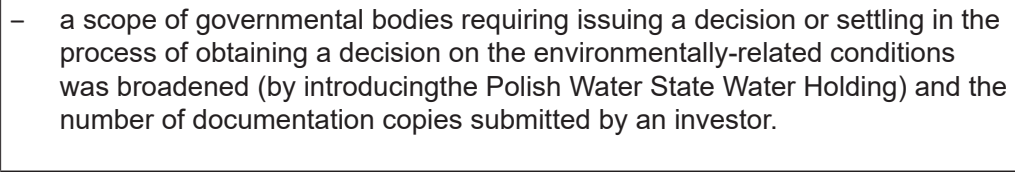 \\
\hline
\end{tabular}

of the basis of assessment documents on appropriate tools and research methods may be a result of inadequate qualifications of people preparing such documents (the enhanced demands for the authors of such documentation have been in force since 1 January 2017). The lack of formal requirements for administrative staff assessing the documentations submitted by investors also influences this situation.

Because of the subject they refer to (building investments of different characteristics and scale of complexity, project of municipal planning documents) and the diversity of effects, environmental impact assessments require numerous, often 


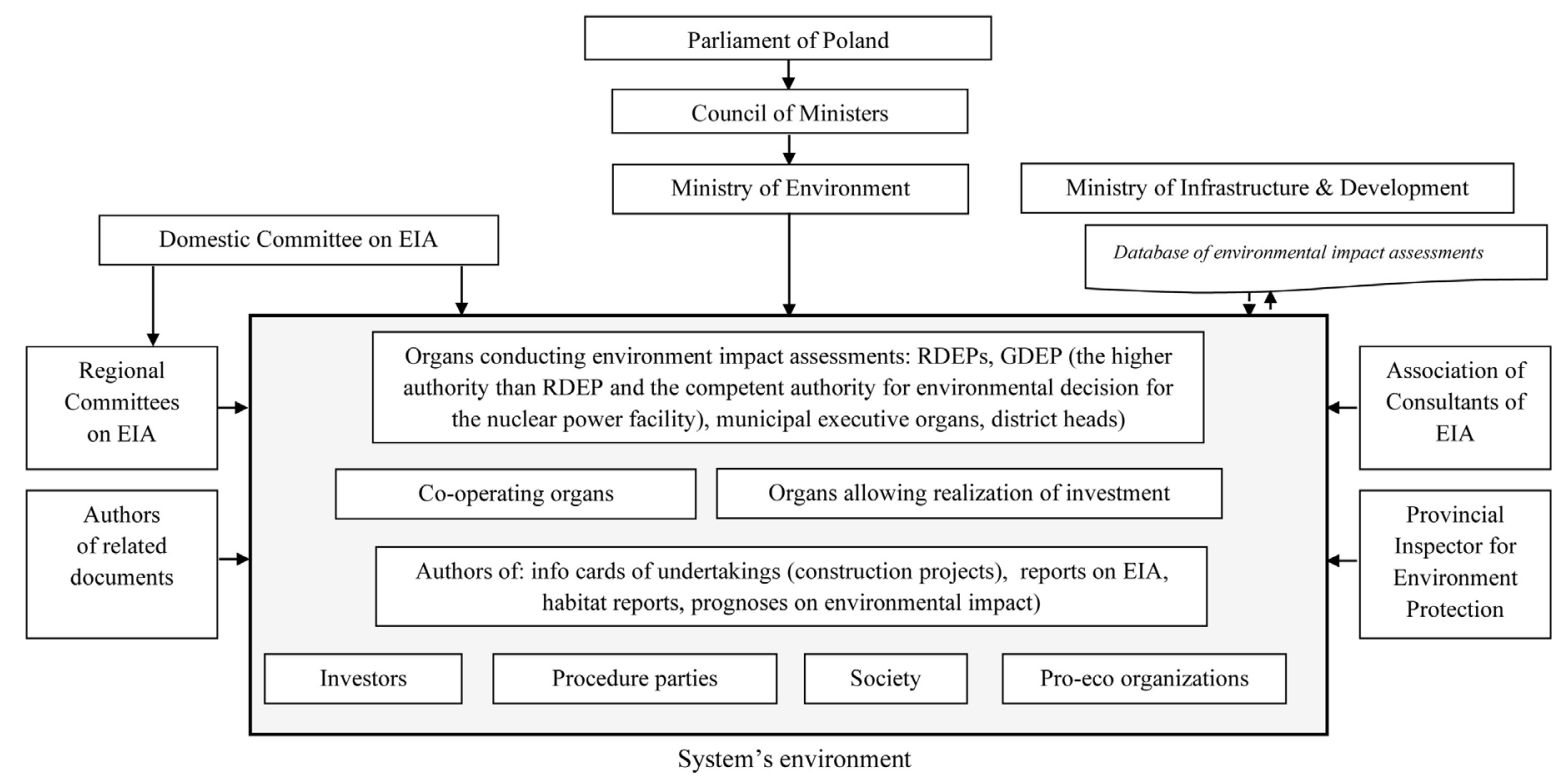

Fig. 2. Organizational system of EIA in Poland

specific, method of conducting work, examination and analyses. Different examination methods were shown in the references [Rak 2014, StrulakWójcikiewicz and Łatuszyńska, 2014, StrulakWójcikiewicz and Lemke, 2019]. However, it was not pointed, which of them are recommended to use in each of the analysed assessments. From the article [Harasymiuk and Drozd 2019] the issues that most often applied the methods of examination in SEA, involved the methods determining the character of the expected changes in the qualitative way (descriptive method, literature and source materials analysis). The inadequateness of the applied examination methods has been also found in the research on the quality of habitat reports. The impact of SFRs on individual elements of the environment was determined most often qualitatively (dividing them into positive, negative and mixed ones).

An environmental impact assessment requires a use of different examination methods for an identification, prognosis and assessment of the impacts on individual elements of the environment.In the analyzed habitat reports, the matrix method was used to identify the impact of SFRs on the Natura 2000 sites (especially on the avifauna of the area, flora and natural habitats, surface and ground waters, the landscape and the local community).The methodical competence pertaining to terrain examination was usually reliably described in the environmental documentation (ornithological and floristic research). In the analyzed prognoses, the descriptive method was commonly used instead of the indicator method to describe the state of the natural environment in the areas covered by the local project plans. It was the reason for an extensive and fuzzy character of these documents. In the analyzed investment impact reports on the environment, a set of the applied research methods was not show in transparent methodological diagrams. It facilitated neither the identification of the research methods nor the analysis of the content of these reports.

Preparation of high-quality documents is difficult because of the lack of detailed requirements in this matter in the 2008 Parliamentary act itself. The existent guidelines for railway the investments and for the investments cofinanced from the EU resources do not have the status of commonly valid rules. The results of the research on the quality of the prognoses submitted in the framework of strategic assessments [Harasymiuk and Drozd 2019] and the habitat reports [Harasymiuk, Szafranko and Tyburski 2019] show the need for preparation of such guidelines. The performed research showed that the authors of prognoses commonly referred to the requirements of already invalid decree of the Minister of Environment of 14 November 2002 on detailed requirements which should be met by a prognosis on environmental impact ${ }^{3}$. In the present legal status, a

\footnotetext{
3 The decree became invalid since 25 June 2005
} 
verdict whether a habitat report meets the formal requirements is not easy, as there are no univocal regulations determining which elements should be taken into account in such a document. There are also no valid guidelines on the preparation of the information cards of an undertaking. On the web pages of selfgovernment units, which receive such cards, the samples of these documents are presented. Most of them do not allow performing a complex analysis for the conditions to conduct a thorough assessment of environmental impact. More precise requirements for basic documents of an EIA, SEA and HA could save the subjects preparing such documents (self-government units, investors) numerous corrections because of failing to meet formal requirements.

\section{CONCLUSIONS}

For an investor, an environmental impact assessment is a tool which enables them to realize a construction project according to the legal rules. The lack of stable and transparent legal regulations makes investors confused and prolongs the conducted administrative procedures as well as increases the preparation costs of building investments. The article presents the most important changes that have been introduced in the regulations in the field since the 2008 Parliamentary act has come into force. In order to ensure the uniformity of the applied law, there is a call for working out an IT database on environmental requirements for preparation and realization of different kinds of building investments (for roads

Table 2. SEA, EIA and HA procedures versus basic methodological problems

\begin{tabular}{|c|c|c|c|c|}
\hline No.. & $\begin{array}{l}\text { Problems areas in } \\
\text { SEA, EIA and HA }\end{array}$ & SEA & EIA & $\mathrm{HA}$ \\
\hline 1. & $\begin{array}{l}\text { Scope of assessment } \\
\text { and its position in an } \\
\text { investment process }\end{array}$ & $\begin{array}{l}\text { The definition of the } \\
\text { assessment presented in the } \\
\text { act (2008) considers only } \\
\text { some elements which hinders } \\
\text { the possibility to prepare a } \\
\text { coherent methodology for } \\
\text { making an SEA. The place of } \\
\text { the assessment is precisely } \\
\text { stated in the regulations } \\
\text { (before submitting a local plan } \\
\text { project). }\end{array}$ & $\begin{array}{l}\text { The definition of the } \\
\text { assessment is incomplete } \\
\text { which does not allow to work } \\
\text { out a coherent methodology. } \\
\text { The place of the assessment } \\
\text { is precisely determined in the } \\
\text { act (2008) - before issuing } \\
\text { a decision on environmental } \\
\text { conditions (full or simplified } \\
\text { version). }\end{array}$ & $\begin{array}{l}\text { The incomplete definition } \\
\text { of the assessment makes } \\
\text { it impossible to prepare } \\
\text { a coherent methodology } \\
\text { of conduct. The place of } \\
\text { a preliminary and proper } \\
\text { assessment is precisely } \\
\text { determined - after issuing } \\
\text { an opinion of the necessity } \\
\text { of conducting a habitat } \\
\text { assessment and before issuing } \\
\text { a permit for realization of an } \\
\text { investment (a decision on } \\
\text { the condition of building, land } \\
\text { development, building permit } \\
\text { and others). }\end{array}$ \\
\hline 2. & $\begin{array}{l}\text { Qualification for } \\
\text { preparation or } \\
\text { exemption from } \\
\text { anassessment }\end{array}$ & $\begin{array}{l}\text { The possibility of exemption } \\
\text { from the assessment is } \\
\text { stated imprecisely. More } \\
\text { precise premises for such an } \\
\text { exemption is required ("lack } \\
\text { of considerable impact on } \\
\text { the environment", "a slight } \\
\text { modification of the document"). } \\
\text { The place of the prognosis in } \\
\text { the procedure of preparing a } \\
\text { planning document was not } \\
\text { determined univocally. }\end{array}$ & $\begin{array}{l}\text { A lack of a uniformed } \\
\text { methodical approach to } \\
\text { the investment qualification } \\
\text { process (undertakings form } \\
\text { group I: method "criteria" } \\
\text { issuing form the act (2008), } \\
\text { undertakings from group II: } \\
\text { method "criteria"/method of } \\
\text { individual assessment). }\end{array}$ & $\begin{array}{l}\text { A lack of a uniformed criteria } \\
\text { system used while qualification } \\
\text { which would allow an objective } \\
\text { justification of the issued } \\
\text { opinion. The conditions issuing } \\
\text { from the act (2008) are used } \\
\text { instead of measureable } \\
\text { criteria. }\end{array}$ \\
\hline 3. & $\begin{array}{l}\text { Methodical guidelines } \\
\text { in a prognosis, } \\
\text { preparation and } \\
\text { assessment } \\
\text { of submitted } \\
\text { documentation }\end{array}$ & $\begin{array}{l}\text { Applicable for forecasting of } \\
\text { natural effects of solutions } \\
\text { adopted in local plans. }\end{array}$ & $\begin{array}{l}\text { Applicable for a few kinds } \\
\text { of building investments and } \\
\text { are not commonly valid legal } \\
\text { regulations. }\end{array}$ & $\begin{array}{l}\text { Applicable for chosen impacts } \\
\text { and are not law-binding. }\end{array}$ \\
\hline 5. & $\begin{array}{l}\text { Methodsfor } \\
\text { conducting work, } \\
\text { research and } \\
\text { analyses }\end{array}$ & $\begin{array}{l}\text { The methodology is } \\
\text { not systematic and fully } \\
\text { developed. In common use } \\
\text { there are methods determining } \\
\text { a character of foreseen } \\
\text { impacts in a qualitative way. }\end{array}$ & $\begin{array}{l}\text { The methodology is not } \\
\text { uniform and fully developed. }\end{array}$ & $\begin{array}{l}\text { The methodology is } \\
\text { not systematic and fully } \\
\text { developed. The methods } \\
\text { determining a character } \\
\text { of foreseen impacts in a } \\
\text { qualitative way are in common } \\
\text { use. }\end{array}$ \\
\hline
\end{tabular}


and railways construction a subject to the habitat assessment, etc.), which could be used by investors and clerks.

Further, thorough research is needed for a database kept by the General Director of Environment Protection, which is a very important element of EIAs. The defectiveness of this subsystem results in limitation of the right of citizens to the information on the condition and protection of the environment, as expressed in the constitution of the Republic of Poland.

An EIA requires different research methods for identification, forecasting and assessing impacts on individual elements of the environment. Several years of the development of strategic assessments in Poland has not allowed, to create a full methodical approach, despite drawing on the European experiences. The article identifies the most important methodological problems which call for a solution in order to conduct effectively SEA, EIA and habitat procedures.

\section{REFERENCES}

1. Act of 8 November 2008 on providing information about the environment and its protection, public participation in environmental protection and environmental impact assessments. Journal of Laws 2017, item 1405.

2. Brodawka M. 2014. The analysis of the implementation of the environmental impact assessment of projects in the Polish legal system. Polish Yearbook of Environmental Law, 4, 27-44.

3. Chylarecki P., Kajzer K., Wysocki D., Tryjanowski P., Wuczyński W. 2011. Guidelines for the impact assessment of wind power plants on birds (project), Warsaw. General Directorate of Environment Protection Publisher.

4. Council Directive 85/337/EEC of 27 June 1985 on the assessment of the effects of certain public and private projects on the environment (Official Journal of European Communities L 175, 5.7.85).

5. Decree of the Council of Minister of 9 November 2010 on undertakings possibly impacting the environment in a significant degree (Journal of Laws 2016, item 71 with amendments).

6. Directive 2001/42/EC of the European Parliament and of the Council of 27 June 2001 on the assessment of the effects of certain plans and programmes on the environment (Official Journal of the European CommunitiesL 197/30 EN 21.7.2001).

7. Directive 2003/4/EC of the European Parliament and of the Council of 28 January 2003 on public access to environmental information and repealing Council Directive 90/313/EEC (Official Journal of the European Union L 41, 14.2.2003).

8. Directive 2011/92/EU of the European Parliament and of the Council of 13 December 2011 on the assessment of the effects of certain public and private projects on the environment (Official Journal of the European Union L 26, 28.1.2012).

9. Directive 2014/52/EU of the European Parliament and of the Council of 16 April 2014 amending Directive 2011/92/EU on the assessment of the effects of certain public and private projects on the environment (Official Journal of the European Union L 124, 25.4.2014).

10. Gerlee A., Kaim 2011. Cumulative impact assessment methods in the EIA procedure - selected aspects. Technical Transaction of Cracow University of Technology, 6-A/2011, Issue 17, Year 108, 107-111.

11. Harasymiuk, J., Drozd, W. 2019. Strategic environmental assessment of spatial plans in the light of own research. Sci. Rev. Eng. Env. Sci., 28 (2), 224-234.

12. Harasymiuk J. 2016. Chosen problemsof obtaining permits for realizationof building investments in Natura 2000 sitesin the province of Warmia and Masuria, Warsaw.University of Technology, Faculty of Mechanics and Petrochemistry, 103-113 (chapter in a monography).

13. Harasymiuk J. 2017. Analysis of selected environmental procedures for construction investment. Ecological Engineering, Vol. 18, Iss. 4, 79-88.

14. Harasymiuk, J., Szafranko E.H., Tyburski, J. 2019. Methods of habitat reports' evaluation. Open Eng., 9, 26-33.

15. Kasprowicz T. 2010. Process of conceptual analysis, designing, organization and exploitation of construction projects. Technical Transactions, 1-B, 177-189.

16. Kepel A., Ciechanowski M., Jaros R. 2011. Guidelines for the impact assessment of wind power plants on bats, Warsaw: General Directorate of Environment Protection(project).

17. Filipowicz T, Plucińska - Filipowicz A, Wierzbowski M (editors). 2017. Act on providing information about the environment and its protection,public participation in environmental protection and environmental impact assessments. Comment, Warsaw. C.H. Beck Publisher.

18. Rak A. 2014. Building investment undertakings. Environmental conditions of preparation and realization, Warsaw. PWN SA Publisher.

19. Rakoczy B., Pchałek M. 2010. Selected problems of environmental law, Warsaw. Wolters Kluwer Publisher. 
20. Smit B., Spaling H. 1995. Methods for cumulative effects assessment. Environmental Impact Assessment Review, 15, 1, 81-106.

21. Strulak-Wójcikiewicz R., Lemke J. 2019. Concept of a Simulation Model for Assessing the Sustainable Development of Urban Transport. Transportation Research Procedia 39, 502-513.

22. Strulak-Wójcikiewicz R., Łatuszyńska M. 2014. Methods of environmental impact assessment. Studies and work of Faculty of Economic Sciences and Management, University of Szczecin, 37(3), 107-115.

23. Stryjecki M., Mielniczuk K. 2011. Guidelines on prognoses of an environmental impact of wind farms, Warsaw. General Directorate of Environment Protection Publisher.

24. Szafranko E. 2015. Multi-criteria methods in an analysis of variants of a construction project. Journal of International Scientific Publications: Materials, Methods \& Technologies, 9, 155-168.

25. Tkaczyński J. W. 2009.European Union law and policy of environmental protection, Warsaw. PWN Publisher.

26. Wärnbäck A., Hilding-Rydevik T. 2009.Cumulative effects in Swedish EIA practice-difficulties and obstacles. EnvironmentalImpact Assessment Review, 29, 107-115.

27. Zalewska A., Komosiński K., Krupa R., Kołodziej P., Szydłowska J. 2013. Methods of conducting natural valorisations. Methodical handbook and companion to terrain classes, Olsztyn. University of Warmia and Mazury in Olsztyn Publisher.

28. Bohatkiewicz J. (editor) 2008. Manual of good practices for carrying out environmental studies for national roads, Cracow. Ekkom Publisher. 